九州大学学術情報リポジトリ

Kyushu University Institutional Repository

Ecological Studies on Formica yessensis Forel, with Special Reference to Its Effectiveness as a Biological Control Agent of the Pine Caterpillar Moth in Korea : II. Bionomics of Formica yessensis Fore1 (Hymenoptera:

Formicidae) in Korea

Kim, Chang Hyo

Division of Insect Natural Enemies, Institute of Biological Control, Faculty of Agriculture, Kyushu University

Murakami, Yozo

Division of Insect Natural Enemies, Institute of Biological Control, Faculty of Agriculture, Kyushu University

https://doi.org/10.5109/23724

出版情報：九州大学大学院農学研究院紀要. 25 (2/3)，pp.119-133，1980-11. Kyushu University バージョン：

権利関係 : 


\title{
Ecological Studies on Formica yessensis Forel, with Special Reference to Its Effectiveness as a Biological Control Agent of the Pine Caterpillar Moth in Korea
}

\section{Bionomics of Formica yessensis Fore1 (Hymenoptera: Formicidae) in Korea}

\author{
Chang Hyo Kim* and Yôzô Murakami \\ Division of Insect Natural Enemies, Institute of Biological Control, Faculty of \\ Agriculture, Kyushu University 46-13, Fukuoka 812 \\ (Received July 15, 1980)
}

\begin{abstract}
The bionomics of Formica yessensis was studied in red pine stands in the Jinju district, Korea, in 1972-77, put emphasis on annual life cycle, nest structure, colony size, ratio of fertile nests, sex ratio and relation between worker size and division of labor. Extranidal activities were observed from April to November. Queens oviposited from mid April to late August. New workers appeared from early July to late October. Nuptial flights by new sexuals were observed from mid July to late August. Only workers and dealated females hibernated. A nest consists of mound and subterranean nest, the former develops as high as $80 \mathrm{~cm}$ in maximum. Number of workers per colony ranged between 1,900 and 100,000 , that of queens between 4 and 278. Sexuals were produced only in large nests, the fertile nests occupying only $17 \%$ of large nests. A supercolony consisted of 31 to 113 colonial nests. Sex ratio of alates varied with nests and males outnumbered females in total, the latter being $27 \%$ of total alates. Size distribution of workers were different with task performance. Smaller workers were mainly engaged in nursing and aphid-visiting, larger workers in hunting and adult-transporting. Workers participated in nest building were intermediate.
\end{abstract}

\section{INTRODUCTION}

There have been serial studies of biology and ecology on the huge population of Formica (Formica) yessensis Fore1 at the Ishikari Shore openland in Hokkaido, Japan. Among these studies, Ito (1973) has published on seasonal population trends and nest structure, Imamura (1974) on hibernation, Ito and Imamura (1974) on nuptial flight and internest relationship, Higashi (1974, 1978 a,b) on worker polyethism, its conservatism in task and area and internest drifting, and Imamura (1978) on adult transport.

In Korea, however, the bionomics of the ant has scarcely been known before the senior author and his collaborators (Kim et al., 1978). From 1972

* Present address: College of Agriculture, Gyeongsang National University, Jinju 620. Korea. 
to 1977 , the senior author investigated the annual life cycle, nest structure, population size, sex ratio and division of labor among workers. In this paper these features of the ant in Korea are presented in comparison with those obtained at Ishikari Shore in Hokkaido.

\section{METHODS}

From 1972 to 1977, the annual life cycle of F. yessensis was investigated by field observations and nest excavations in several red pine stands in the Jinju district in order to know primarily the beginning of extranidal activities by post-hibernating workers, the oviposition by queens, the appearance of larvae, pupae and new workers, the nuptial flight of new sexuals and hibernations.

From April to October, 1973, nest structure was investigated in a red pine stand at Jinseung, Jinyang-gun. Height and basal diameter of nest mounds were measured, then these nests were excavated to investigate their structure and number of workers. To count the number of workers, 50 nests were excavated and all the workers were collected and put in a cloth bag with nesting material. Prior to the excavation, the nests were covered with ethylene sheet and smoked with $\mathrm{CS}_{2}$ to paralyze ants early in the morning around 6 o'clock.

In order to investigate seasonal population trends of workers and queens per nest, 3 nests for each class in nest size were excavated monthly from April to October, 1975-77 in the same stand. Nests were classified into three classes in size for the sake of convenience; i.e., the large nests being more than $30 \mathrm{~cm}$ in basal diameter of mounds, the medium $18-30 \mathrm{~cm}$, the small less than $18 \mathrm{~cm}$.

$\boldsymbol{F}$. yessensis has been known to produce sexuals in only a fraction of nest population (Ito and Imamura, 1974). In order to know the ratio of fertile nests and number of nests in each supercolony, 1216 nests were inspected in 20 red pine stands at Jinyang, Sacheun, Goseung, Sancheung, Hadong and Namhae (see Fig. 1 in Kim and Murakami, 1980) during mid August, 1974-75.

In order to estimate the sex ratio of the ant, 26 large (fertile) nests were excavated in 7 red pine stands at Jinseung, Chunggok Temple, Goseung, Guam, Gonyang, Namhae and Mt. Jiri (see Fig. 1 in Kim and Murakami, 1980) from mid to late August, 1976. All the winged female and male ants and pupae were collected, of which the sex of pupae was determined with their size and genital organs.

The body size of $\boldsymbol{F}$. yessensis workers is observed to be variable. The relation of task performance to it has been known in the population at Ishikari Shore, Hokkaido (Higashi, 1974). To estimate the seasonal trends of body size of workers emerged, the length of pupal cocoons was measured monthly from mid June to mid October, 1975. The collection of cocoons was carried out from large, medium and small nests in a red pine stand at Sacheun. To investigate the relation of worker body size to task performance, workers performing different tasks were collected and measured from a natural habitat in a red pine stand at Jinseung from $10: 00$ to $17: 00$, July 20, 1976. The tasks 
were divided into five categories; i.e., hunting, nest-building, nursing, adulttransporting and aphid-visiting activities. In order to investigate the seasonal change of the division of labor among workers, a supplemental sampling of aphid-visiting workers was carried out in the same forest stand on October 5 . Prior to these investigations, body size of hibernating workers was measured which were collected from a nest by excavation in March. As for the measurement of body size, Lee (1938) adopted body length from front of mandibles to gastric tip in Camponotus japonicus var. aterrimus Emery. Higashi (1974) chose the maximum outerorbital distance as the index for body size of $F$. yessensis. In the present study the maximum outerorbital distance was adopted.

\section{RESULTS AND DISCUSSION}

Annual cycle of colony activities and breeding

1) Beginning of extranidal activities by post- hibernating workers

Extranidal activities by post-hibernating workers began in early April, but the period may be delayed more or less depending on places and years. As the temperatute was low at this time, the activity was still at a low level. It became gradually active as the temperature rised with season. In Hokkaido, the extranidal activity begins in mid April just after thawing, and becomes active at late May when the honey dew secreted by aphids becomes available (Ito, 1973).

\section{2) Oviposition}

The queens began to oviposit in mid April. On excavation of nests, eggs were observed until late August in a few nests. Thus, the oviposition was seemed to be continued for approximately 4 months, being most active from early June to early August. In Hokkaido, the period of oviposition lasts from early May to late July (Ito, 1973).

\section{3) Appearance of larvae and pupae}

Larvae were found in nests in early May first and observed till September. The larvae were most abundant from mid June to late August. Pupae appeared in mid June and remained till mid October. The maximum number of pupae was observed from early July to late September. These data show that larvae and pupae are present in nests in the Jinju district for longer period than in Hokkaido (Ito, 1973).

\section{4) Appearance of new workers}

New workers appeared in early July and the emergence continued till late October in nests. The maximum number of workers emerged from late July to mid September. In Hokkaido, they emerge from early August to mid September, slightly after the emergence of new sexuals (Ito, 1973).

5) Nuptial flight and mating

Nuptial flights were observed from mid July to late August in the Jinju district. Observations of the flight activity were made three times. The results are as follows. The flights were observed between $5: 00$ and $7: 00$ in 
the morning of fine and warm days. After flown up to about $1 \mathrm{~m}$ high, the alates alighted on herbs and shrubs and copulated there. Copulation lasted 50 seconds to 6 minutes. After mating females descended to the ground and returned to the mother nests. Some females, however, did not enter nests but rambled. To these rambling females, a number of workers aggregated, then the females searched nesting sites together with workers to found new nests. The wings of these queens were casted off by these workers.

Ito and Imamura (1974) have intensively observed the nuptial flight and mating behaviour at Ishikari Shore in Hokkaido in August, 1971. They estimated the flight season as late July to mid August. They observed that alates emerged from nests onto the nest surface between $5: 00$ and $5: 30$ and disappeared between 7: 55 and 8: 20. After climbing herbs and grasses nearby nests, males flew up to about 0.5 to $1 \mathrm{~m}$ high. They did not observe the flight by alate females prior to copulation. After alighted on the plant, males approached females and copulated. Copulation lasted 30 seconds to 9 minutes.

\section{6) Hibernation}

Extranidal activities of workers dropped in mid October and ceased in November. Only workers and dealated females (queens) hibernated in subterranean nests till next $\mathrm{March}$.

Nest structure and colony inhabitants

1) Nest structure and its utilization

A nest consisted of two parts, mound and subterranean nest. The mound (Fig. 1) was constructed with various broken vegetable matters mainly of dead leaves and twigs of red pine trees. Mound size varied with its developmental degrees. Basal diameter of mounds ranged between approximately 5 $\mathrm{cm}$ in young nests and more than $\mathrm{Im}$ in well-developed ones. Height of mounds ranged between approximately $10 \mathrm{~cm}$ and $80 \mathrm{~cm}$.

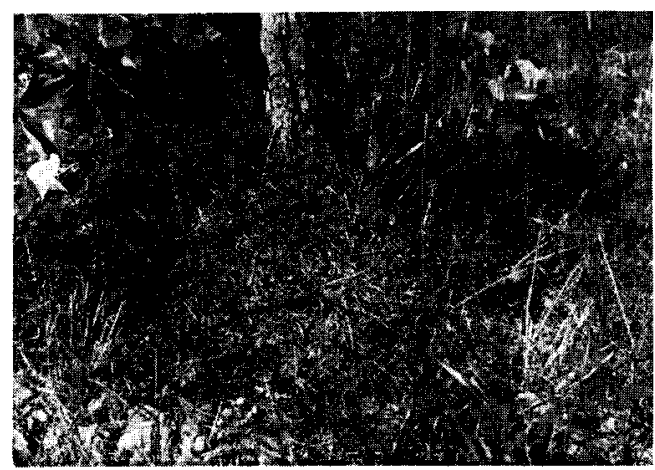

Fig. 1. A mound of nest of $F$. yessensis in a pine stand in the Jinju district, Korea.

Some relations were recognized between basal diameter and height of mounds (Fig. 2). However, the height of mounds was sometimes influenced 
by such events as colapsing by heavy rains and other physical factors, and by decaying of pine leaves and other nest materials inside nests, therefore it was not reliable as the index of nest size. In the Ishikari Shore openland the mound does not develop well partly because of the poverty of building materials and some local climate conditions which may decrease mound building activity (Ito, 1973). In the red pine forests in Korea it developed much well than in Ishikari Shore because of the plenty of building materials.

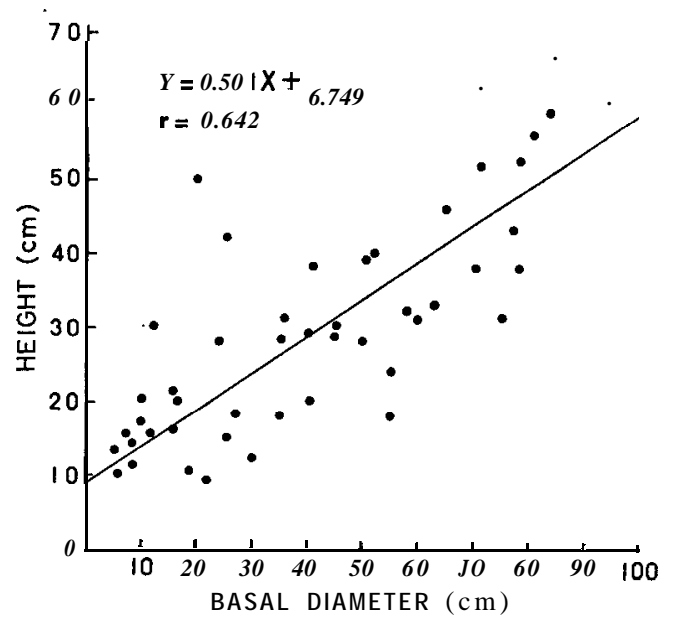

Fig. 2. Relation between basal diameter and height of mounds in a red pine stand at Jinseung in the Jinju district.

The mound was utilized as the breeding site of mature larvae and pupae. On the hot day in summer, they were put in a upper portion of the mound at night whereas they were moved to the deeper portion in the daytime. Sometimes, workers built a temporary nest which lacked a subterranean part in the shade beside a pine tree several meters apart from the mother nest where they transported larvae and pupae in the daytime to protect from the exposure to solar radiation, then returned them to the mother nest in the evening. This type of nest has been called as the incipient or bivouac nest by Ito (1973). Thus, it is obvious that the mound was prepared to protect the brood from heating in summer.

The mound was also serves as the pupation site. The larvae were observed pupating in the deeper portion of a mound where workers transported up the mature larvae immediately before pupation from the subterranean nest. Observations in summer showed the pupae just after pupation were placed in the deeper portion of nests whereas those just before emergence were placed in the upper portion.

The subterranean nest consisted of brood section and vertical shafts, the former being made immediately beneath the mound and the latter descending down from the former. At the midway of the vertical shafts, small chambers and larger oval chambers were sometimes observed. 
The brood section was utilized as the breeding site of eggs, larvae and pupae from spring to autumn. Up and down transportation of the brood with variable temperature and moisture was also observed in the brood section as in the mound. The vertical shaft was utilized as the passage of workers, the small chamber as the food-storing site where a number of workers aggregated, and the oval chamber as the ovipositing site where larvae and pupae were being nursed by numerous workers surrounding queens. The oval chambers were frequently observed at the bottom portions of the subterranean nests. Queens hibernate in the bottom oval chambers in winter, then they move to the upper oval chambers after April.

\section{2) Relation between nest size and colony size}

Relation between basal diameter of mounds (nest size) and number of workers per nest (colony size) is shown in Fig. 3. These data are based on the investigations of 50 nests excavated at a natural habitat in a red pine stand at Jinseung from May to September, 1973. Individual number of workers per nest ranged between 1,900 and 100,000. The relation is represented by two regression lines. In smaller nests with their basal diameter of mounds less than $30 \mathrm{~cm}$, number of workers gradually increases with nest size, while in larger ones the slope is steeper.

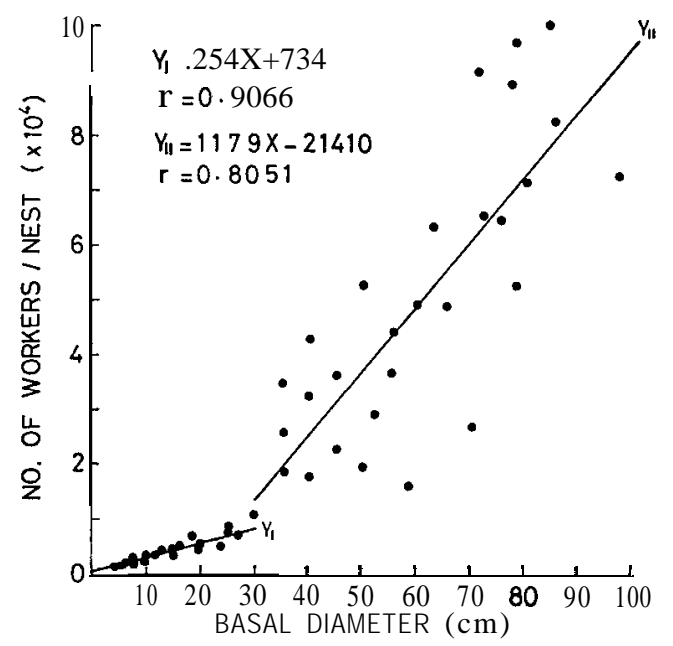

Fig. 3. Relation between basal diameter of mounds and worker population size in a red pine stand at Jinseung.

Ito (1973) stated that the adult population per nest was generally proportional to the nest diameter in the population at Ishikari Shore, but he did not calculate the regression. Based upon his crude data on number of workers (Appendix I in Ito, 1973) and on nest diameter (Appendix II in the same paper), the regression line was calculated and compared with Jinseung population (Fig. 4). So far as the nests larger than $30 \mathrm{~cm}$ in basal diameter were 
concerned, number of workers per nest in Ishikari Shore was considerably less than in the Jinseung red pine stand. The difference seems to come from differences in the environmental conditions in nesting site between them; i.e., amount and kind of nesting material available, soil texture and underground water level.

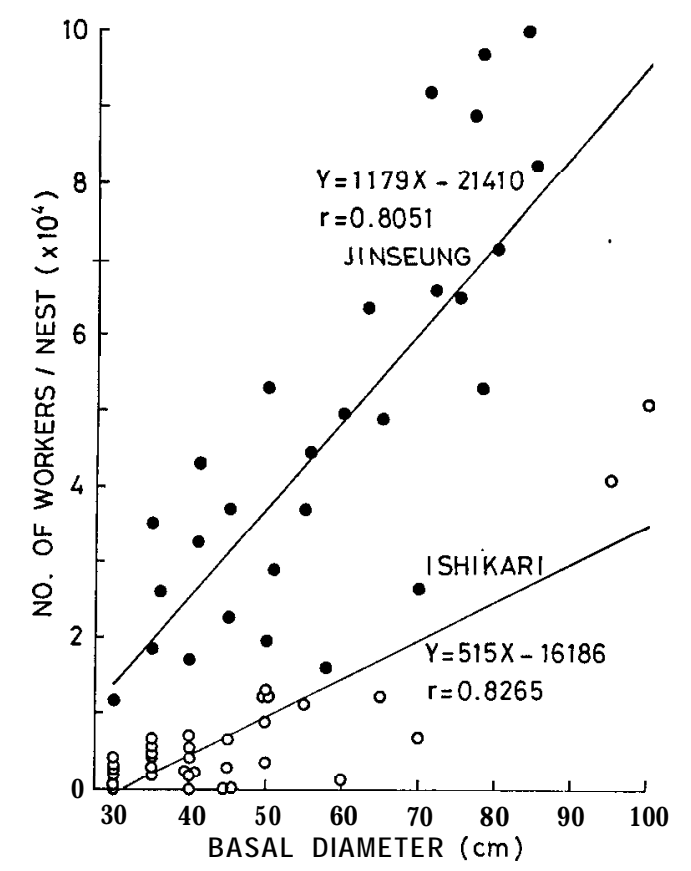

Fig. 4. A comparison of the relation between nest diameter and worker population in Korea (Jinseung) and Japan (Ishikari Shore).

3) Seasonal trends of worker and queen number per nest

F. yessensis has some peculiar mode of life. Nests often stand closely nearby and interconnected by the drifting of inhabitants, forming a polydomous system. Due to this peculiarity, the individuals sampled in a given nest are not necessarily those produced there (Ito, 1973). Such polydomous ants often ensure their colony multiplication by budding. That is, new colonies are established by the departure of a group of workers from one nest to the site nearby, which later transport the queens from the mother nest or adopt new queens soon after nuptial flight. $F$. yessensis al so exhibits such proliferation of nests by budding (Ito, 1973; Higashi, 1976). Thus, the number of adult inhabitants changes seasonally.

Fig. 5 shows the seasonal trends of the average number of workers and queens per nest and the queen worker ratio for three years (1975-77) in the natural habitat at Jinseung. The tendency of the seasonal change in number of workers and queens was similar with each other among small, medium and 

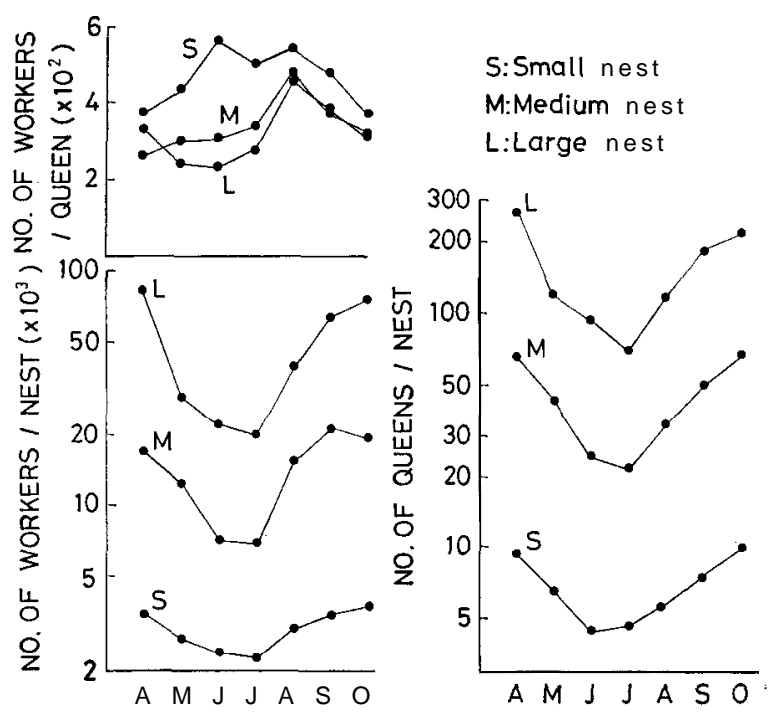

Fig. 5. Seasonal trends of worker and queen number and queen worker ratio in a red pine stand at Jinseung. The data refer the mean number for three years (1975-77).

large nests, decreasing till July and increasing afterwards. The decrease in number of workers and queens per nest from May to July can be explained by the fact that the proliferation by budding is frequent in the period. The number of queens per nest ranged between 4 (small nests in June) and 278 (large nests in April), showing that this ant exhibited a polygynous system.

The queen worker ratio ranged between $1: 278$ (large nests in June) and 1: 576 (small nests in June). Comparing with the number of workers and queens per nest, the ratio was not largely different with nest size and did not much fluctuate seasonally.

However, the seasonal trends of the ratio from April to August were different with nest size. In small nests the number of workers per queen increased (that is, queen ratio decreasing) from April to June, while in large ones it decreased, medium ones intermediate. Ito (1973) showed that the ratio in the Ishikari Shore population was $1: 340$ and the lower number of workers per queen were relatively frequent in spring and autumn than in summer.

\section{4) Ratio of fertile nests and number of nests per supercolony}

Ito and Imamura (1974) investigated the ratio of fertile nests producing sexuals in July, 1971, at Ishikari Shore, and stated that only 11 out of 178 nests examined or $6.4 \%$ contained sexual pupae but it was slightly underestimated. For a better estimation, they considered the budding frequency because young nests formed by budding might not produce sexuals, and estimated the real ratio of fertile nests among more or less established nests as $13.7 \%$. They also stated that fertile nests tended to have larger mounds than sterile ones.

In the Jinju district, Korea, only 90 out of 1,216 nests examined or $7.4 \%$ 
Table 1. Number of fertile nests out of small, medium and large nests examined in mid August, 1974-75. The nest size is classified by the basal diameter of its mound into three classes; small (less than $18 \mathrm{~cm}$ ), medium $(18-30 \mathrm{~cm})$ and large (more than $30 \mathrm{~cm})$.

\begin{tabular}{|c|c|c|c|c|c|c|}
\hline \multirow{2}{*}{ Locality } & \multirow{2}{*}{ Station } & \multirow{2}{*}{$\begin{array}{l}\text { Total no. } \\
\text { of nests } \\
\text { examined }\end{array}$} & \multicolumn{3}{|c|}{$\begin{array}{l}\text { No. of fertile nests } \\
\text { (numerators)/No. of nests } \\
\text { examined (denominators) }\end{array}$} & \multirow{2}{*}{$\begin{array}{l}\text { Percentage } \\
\text { of fertile } \\
\text { nests }\end{array}$} \\
\hline & & & $\begin{array}{l}\text { Small } \\
\text { nests }\end{array}$ & $\begin{array}{l}\text { Medium } \\
\text { nests }\end{array}$ & $\begin{array}{l}\text { Large nests } \\
\text { (percentages } \\
\text { in parentheses) }\end{array}$ & \\
\hline Jinyang & $\begin{array}{l}\mathrm{A} \\
\mathrm{B} \\
\mathrm{C}\end{array}$ & $\begin{array}{r}46 \\
113 \\
72\end{array}$ & $\begin{array}{l}0 / 27 \\
0 / 16 \\
0 / 12\end{array}$ & $\begin{array}{l}0 / 9 \\
0 / 39 \\
0 / 20\end{array}$ & $\begin{array}{l}2 / 10(20.0) \\
13 / 58(22.4) \\
8 / 40(20.0)\end{array}$ & $\begin{array}{r}4.3 \\
11.5 \\
11.1\end{array}$ \\
\hline Sacheun & $\begin{array}{l}A \\
B \\
C \\
D \\
E\end{array}$ & $\begin{array}{l}67 \\
56 \\
43 \\
60 \\
60\end{array}$ & $\begin{array}{l}0 / 23 \\
0 / 19 \\
0 / 16 \\
0 / 12 \\
0 / 17\end{array}$ & $\begin{array}{l}0 / 19 \\
0 / 13 \\
0 / 10 \\
0 / 16 \\
0 / 11\end{array}$ & $\begin{array}{l}3 / 25(12.0) \\
6 / 24(25.0) \\
3 / 17(17.6) \\
7 / 32(21.9) \\
6 / 32(18.8)\end{array}$ & $\begin{array}{r}4.5 \\
10.7 \\
7.0 \\
11.7 \\
10: 0\end{array}$ \\
\hline Goseung & $\begin{array}{l}\mathrm{A} \\
\mathrm{B}\end{array}$ & $\begin{array}{l}80 \\
83\end{array}$ & $\begin{array}{l}0 / 20 \\
0 / 23\end{array}$ & $\begin{array}{l}0 / 23 \\
0 / 26\end{array}$ & $\begin{array}{l}7 / 37(18.9) \\
2 / 34(5.9)\end{array}$ & $\begin{array}{l}8.8 \\
2.4\end{array}$ \\
\hline Sancheung & $\begin{array}{l}\mathrm{A} \\
\mathrm{B} \\
\mathrm{C}\end{array}$ & $\begin{array}{l}65 \\
45 \\
65\end{array}$ & $\begin{array}{l}0 / 30 \\
0 / 20 \\
0 / 16\end{array}$ & $\begin{array}{l}0 / 16 \\
0 / 10 \\
0 / 21\end{array}$ & $\begin{array}{l}2 / 19(10.5) \\
2 / 15(13.3) \\
4 / 28(14.3)\end{array}$ & $\begin{array}{l}3.1 \\
4.4 \\
6: 2\end{array}$ \\
\hline Hadong & $\begin{array}{l}\mathrm{A} \\
\mathrm{B} \\
\mathrm{C}\end{array}$ & $\begin{array}{l}65 \\
77 \\
51\end{array}$ & $\begin{array}{l}0 / 15 \\
0 / 21 \\
0 / 27\end{array}$ & $\begin{array}{l}0 / 20 \\
0 / 22 \\
0 / 10\end{array}$ & $\begin{array}{l}3 / 30(10.0) \\
4 / 34(11.8) \\
2 / 14(14.3)\end{array}$ & $\begin{array}{l}4.6 \\
5.2 \\
3.9\end{array}$ \\
\hline Namhae & $\begin{array}{l}\mathrm{A} \\
\mathrm{B} \\
\mathrm{C} \\
\mathrm{D}\end{array}$ & $\begin{array}{l}31 \\
51 \\
40 \\
46\end{array}$ & $\begin{array}{l}0 / 16 \\
0 / 15 \\
0 / 17 \\
0 / 11\end{array}$ & $\begin{array}{l}0 / 5 \\
0 / 12 \\
0 / 7 \\
0 / 9\end{array}$ & $\begin{array}{l}2 / 10(20.0) \\
5 / 24(20.8) \\
4 / 16(25.0) \\
6 / 26(19.2)\end{array}$ & $\begin{array}{r}6.5 \\
9.8 \\
10.0 \\
10.9\end{array}$ \\
\hline Total & & 1216 & $0 / 373$ & $0 / 318$ & $90 / 525(17.1)$ & 7.4 \\
\hline
\end{tabular}

were fertile nests which produced sexuals (Table 1). All the fertile nests were included in large nests larger than $30 \mathrm{~cm}$ in basal diameter of mounds.

F. yessensis has a supercolonial system (Higashi, 1978 a). Ito (1971) estimated the number of nests established in an area of 400 ha at Ishikari Shore as 72,000 . These nests are regarded as a supercolony. The nests in each station in the Jinju district shown in Table 1 constitutes each supercolony. The number of nests per supercolony in these natural habitats ranged between 31 (Namhae A) and 113 (Jinyang B), the average being 61 (Table 1). Comparing with the supercolony in Ishikari Shore, those in the Jinju district are extremely small in size. However, this does not necessarily mean supercolonies in Korea are smaller than those in Hokkaido, because a small supercolony comprising only 3 nests has been recorded at Tsukisappu, Sapporo, Hokkaido (Imamura, 1976). Instead, the supercolony in Ishikari Shore is exceptionally large.

5) Sex ratio

The result of sex ratio investigated by excavation 26 nests in the Jinju district is shown in Table 2. The sex ratio varied considerably with nests ranging from that producing only males (Gonyang No. 1) to that with females 
Table 2. Sex ratio of $F$. yessensis examined in August, 1976.

\begin{tabular}{|c|c|c|c|c|c|c|c|c|}
\hline \multirow{2}{*}{ Locality } & \multirow{2}{*}{$\begin{array}{c}\text { Nest } \\
\text { no. }\end{array}$} & \multicolumn{3}{|c|}{$\begin{array}{l}\text { No. of winged } \\
\text { females }\end{array}$} & \multicolumn{3}{|c|}{ No. of males } & \multirow{2}{*}{$\begin{array}{l}\text { Female / } \\
\text { (Female } \\
\quad \text { + male) }\end{array}$} \\
\hline & & Adult & Pupa & Total & Adult & Pupa & Total & \\
\hline Jinseung & $\begin{array}{l}1 \\
2 \\
3\end{array}$ & $\begin{array}{r}83 \\
0 \\
4\end{array}$ & $\begin{array}{r}28 \\
11 \\
1\end{array}$ & $\begin{array}{r}111 \\
11 \\
5\end{array}$ & $\begin{array}{r}585 \\
67 \\
130\end{array}$ & $\begin{array}{r}67 \\
8 \\
3\end{array}$ & $\begin{array}{r}652 \\
75 \\
133\end{array}$ & $\begin{array}{l}0.15 \\
0.13 \\
0.04\end{array}$ \\
\hline $\begin{array}{c}\text { Chunggok } \\
\text { Temple }\end{array}$ & $\begin{array}{l}3 \\
4\end{array}$ & $\begin{array}{r}188 \\
51\end{array}$ & $\begin{array}{r}135 \\
18 \\
21 \\
19\end{array}$ & $\begin{array}{r}269 \\
152 \\
49 \\
70\end{array}$ & $\begin{array}{r}468 \\
37 \\
175 \\
50\end{array}$ & $\begin{array}{l}212 \\
121 \\
114 \\
107\end{array}$ & $\begin{array}{l}680 \\
158 \\
289 \\
157\end{array}$ & $\begin{array}{l}0.28 \\
0.49 \\
0.14 \\
0.31\end{array}$ \\
\hline Goseung & $\begin{array}{l}1 \\
2 \\
3\end{array}$ & $\begin{array}{r}114 \\
18 \\
1020\end{array}$ & $\begin{array}{r}16 \\
31 \\
117\end{array}$ & $\begin{array}{r}130 \\
49 \\
1137\end{array}$ & $\begin{array}{r}21 \\
4 \\
0\end{array}$ & $\begin{array}{r}0 \\
15 \\
18\end{array}$ & $\begin{array}{l}21 \\
19 \\
18\end{array}$ & $\begin{array}{l}0.86 \\
0.72 \\
0.98\end{array}$ \\
\hline Guam & $\begin{array}{l}1 \\
2 \\
3\end{array}$ & $\begin{array}{r}1 \\
10 \\
5\end{array}$ & $\begin{array}{r}0 \\
29 \\
8\end{array}$ & $\begin{array}{r}1 \\
39 \\
13\end{array}$ & $\begin{array}{r}53 \\
669 \\
226\end{array}$ & $\begin{array}{r}0 \\
21 \\
35\end{array}$ & $\begin{array}{r}53 \\
690 \\
261\end{array}$ & $\begin{array}{l}0.02 \\
0.05 \\
0.05\end{array}$ \\
\hline Gonyang & $\begin{array}{l}1 \\
2 \\
3 \\
4\end{array}$ & $\begin{array}{r}0 \\
18 \\
1 \\
8\end{array}$ & $\begin{array}{r}\mathbf{0} \\
0 \\
0 \\
26\end{array}$ & $\begin{array}{r}0 \\
18 \\
1 \\
34\end{array}$ & $\begin{array}{r}73 \\
139 \\
255 \\
886\end{array}$ & $\begin{array}{r}0 \\
13 \\
0 \\
51\end{array}$ & $\begin{array}{r}73 \\
152 \\
255 \\
937\end{array}$ & $\begin{array}{l}0 \\
0.11 \\
0.00 \\
0.04\end{array}$ \\
\hline Namhae & $\begin{array}{l}1 \\
2 \\
3\end{array}$ & $\begin{array}{r}253 \\
27 \\
13\end{array}$ & $\begin{array}{r}61 \\
4 \\
5\end{array}$ & $\begin{array}{r}314 \\
31 \\
18\end{array}$ & $\begin{array}{r}493 \\
1700 \\
34\end{array}$ & $\begin{array}{r}242 \\
95 \\
105\end{array}$ & $\begin{array}{r}735 \\
1795 \\
139\end{array}$ & $\begin{array}{l}0.30 \\
0.02 \\
0.11\end{array}$ \\
\hline Mt. Jiri & $\begin{array}{l}1 \\
2 \\
4 \\
5\end{array}$ & $\begin{array}{r}164 \\
141 \\
133 \\
\text { 20 } 12 \\
\\
4\end{array}$ & $\begin{array}{r}0 \\
57 \\
66 \\
30 \\
5 \\
3\end{array}$ & $\begin{array}{r}164 \\
198 \\
199 \\
50 \\
17 \\
7\end{array}$ & $\begin{array}{r}207 \\
138 \\
14 \\
200 \\
178 \\
41\end{array}$ & $\begin{array}{r}\mathbf{0} \\
12 \\
0 \\
128 \\
36 \\
19\end{array}$ & $\begin{array}{r}207 \\
150 \\
14 \\
328 \\
214 \\
60\end{array}$ & $\begin{array}{l}0.44 \\
0.57 \\
0.93 \\
0.13 \\
0.07 \\
0.10\end{array}$ \\
\hline Total & & 2396 & 691 & 3087 & 6843 & 1422 & 8265 & 0.27 \\
\hline
\end{tabular}

98\% (Goseung No. 3). Usually, males outnumbered females, the female ratio being $27 \%$ in total. Nests where females outnumbered males (female ratio being more than 0.5) were only 5 out of 26 ones. This shows a striking contrast to the result reported by Ito and Imamura (1974) in colonies at Ishikari Shore where the sex ratio was approximately $1: 1$.

Scherba (1961) observed on reproduction of a North American ant, Formica (Formica) opaciventris Emery and reported that some nests produced only males, some only females, others both males and females, and that nests produced only males were more numerous than those produced only females and both sexes. He also stated that males and females were observed in a ratio of approximately $18: 1$. Talbot (1959) observed flights by sexuals of Formica obscuripes Fore 1 in Michigan for two weeks from mid to late June and recorded more than 4,500 males and 695 females from a nest. Talbot (1964) also reported on Fomnica obscuriventris Mayr, another North American ant, that 2, 587 males and 422 females flew from a colony from late July to late August. Thus, many species of the genus Formica produce more males than females. Therefore, it is undoubtedly exceptional that the sex ratio was $1: 1$ in the colonies of $F$. yessensis in Ishikari Shore. 


\section{Division of labor among workers with reference to their body size 1) Seasonal change in body size of workers}

Fig. 6 shows the seasonal change in length of pupal cocoons of workers excavated monthly from small, medium and large nests. Regardless of the nest size, relatively high ratio of small workers emerged from June to August, particularly in July. In September and October, however, medium workers emerged in relatively high ratio. Thus, size of workers tended to increase from summer to autumn.

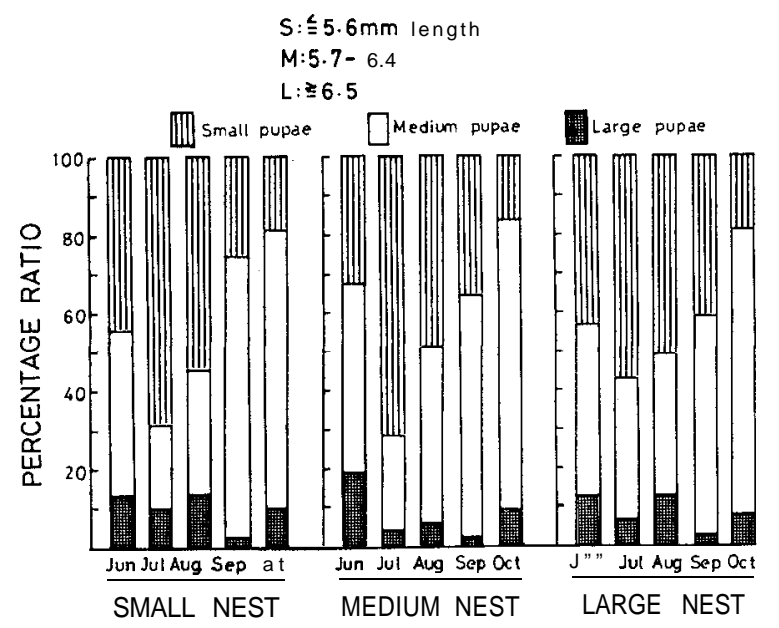

Fig. 6. Seasonal change of pupal size of workers in small, medium and large nests excavated in a red pine stand at Sacheun in the Jinju district.

\section{2) Relation betw en worker size and division of labor}

Using the measurement of the maximal outerorbital distance as index for body size, the workers were divided into three classes; small (less than 1.3 $\mathrm{mm}$ ), medium (1.3-1. $5 \mathrm{~mm}$ ) and large (larger than $1.5 \mathrm{~mm}$ ).

The size distributions in workers performing different tasks in July and hibernating workers are shown in Fig. 7.

From a hibernating nest, 433 workers were collected and measured. The percentage ratios of small and medium workers were $38.6 \%$ and $50.1 \%$ respectively while large workers only $11.3 \%$. The mean size was $1.35 \mathrm{~mm}$ (Fig. $7 \mathrm{~F})$.

The size distribution in 120 individuals of hunting worker followed the normal curve, but the percentage of small worker decreased, occupying only 5.8 $\%$ while medium worker $65.8 \%$ and large worker $28.3 \%$. The mean was 1.51 $\mathrm{mm}$ (Fig. 7A). Thus, the workers which do hunting are mostly medium and large in size.

Imamura (1978) observed at Ishikari Shore that live workers of F.yessensis were sometimes transported by other workers of the same species with mandibles between nests. He stated that the adult transport was frequent in spring and that transporters were as large as hunters and transportees similar 
to thatchers and diggers. He concluded the adult transport seemed to promote the expansion of nests because it was likely that transportees participate in digging in target nests. In the natural habitat at Jinseung, 117 workers performing adult transport were collected and measured. The size distribution was similar to that of hunting workers with the percentage ratios of small, medium and large workers $3.4 \%, 59.8 \%$ and $36.8 \%$ respectively, giving a slightly higher mean size $1.56 \mathrm{~mm}$ (Fig. 7B). It means the workers who perform adult transport are almost equal in size to hunters, and the result mentioned here agrees with that by Imamura (1978).

Nest building task includes extranidal building activities carrying nest materials and founding mounds on the nest surface and intranidal building ones carrying sand particles from inside to outside of the nest. 408 individuals performing such task were collected and measured. The percentage of small individuals was distinctly higher than in case of hunting and adult-transporting, occupying $23.8 \%$, while large workers decreased to $17.4 \%$ with a decrease of the mean to $1.40 \mathrm{~mm}$ (Fig. 7C). Among them workers who carried nest mate-

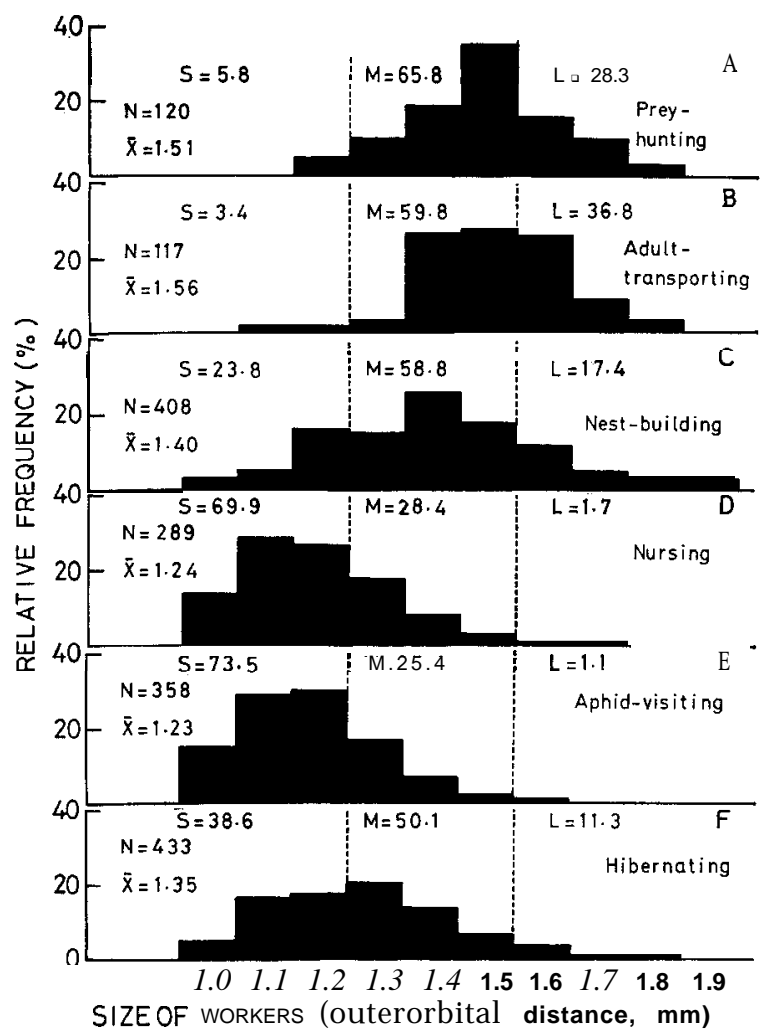

Fig. 7. Size distributions of workers performing different tasks in July $(A-E)$ and a hibernating colony $(F)$ in a red pine stand at Jinseung. $N$ : Total number of individuals measured. $\overline{\mathrm{x}}$ : Mean size. $\mathrm{S}, \mathrm{M}, \mathrm{L}$ : Percentage ratios of small, medium and large workers. 
rials were rather larger than those engaged in intranidal building. Higher percentage of medium and small workers was observed in the nest-building activities as a whole.

Some workers were observed in nests nursing the eggs, larvae, pupae and queens, sometimes carrying them for protecting from variable environmental conditions such as high temperature and humidity. 289 workers performing such activities were collected and measured. The percentage of small individuals was extremely high, attaining $69.9 \%$, medium workers occupying $28.4 \%$ while large workers only $1.7 \%$, giving a very low mean size $1.24 \mathrm{~mm}$ (Fig. 7D). That is, workers who participate in nursing activities are mostly small and medium in size.

In red pine forests in Korea, many workers of F. yessensis visit aphids, Cinara piniformosa Takahashi to collect honey dew. 358 individuals of such workers were collected and measured. The size distribution was very similar to that of nursing workers with the percentage ratios of small, medium and large workers $73.5 \%, 25.4 \%$ and $1.1 \%$ respectively, giving a mean size 1.23 $\mathrm{mm}$ (Fig. 7E). Thus, aphid-visiting workers are mostly small and medium individuals, and large workers scarcely participate in the task.

However, the size distribution of aphid-visiting workers varied according to the season. On October 5, 221 aphid-visiting workers were collected and measured. As shown in Fig. 8, medium and large individuals apparently increased to $51.1 \%$ and $14.0 \%$ respectively, and small ones decreased to $34.8 \%$, the mean increasing $1.34 \mathrm{~mm}$.

As mentioned above, F. yessensis exhibits a marked correlation between task performance and body size of workers. Smaller workers are engaged in nursing and aphid-visiting in summer. On the other hand, larger individuals participate in hunting and adult-transporting tasks. Workers who participate in nest-building activities are intermediate between hunting and nursing workers. However, the size-linked polyethism is not firmly fixed but plastic seasonally as shown in difference in size distributions of aphid-visiting workers between in summer and autumn. The difference may be reflected in part by the seasonal change in body size of workers. Besides, it may be because larg-

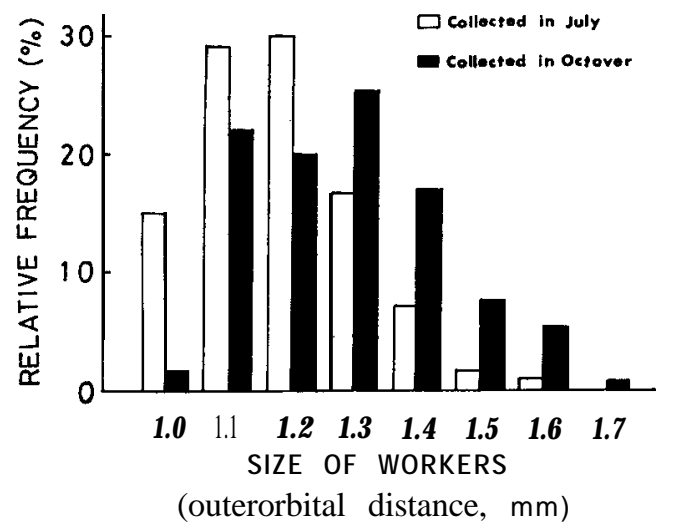

Fig. 8. Size distributions of aphid-visiting workers in summer and autumn. 
er workers which do hunting in summer might change their task to aphidvisiting for decrease in prey densities in autumn. According to Higashi (1978 a), most workers might be able to practice most tasks during their life, though the degree of conservatism to each task is different among workers.

Higashi (1974) studied the relation between task performance and body size in $F$. yessensis at Ishikari Shore and concluded that smaller workers were apt to make intranidal tasks and aphid-visiting and larger ones hunting, and that workers who participate in building activities are intermediate between nursers and hunters. The results obtained in the present study agree well with those at Ishikari Shore.

\section{ACKNOWLEDGEMENTS}

The authors wish to express their hearty thanks to Professor $\mathrm{Y}$. Hirashima for his constant guidance and critical reading of the manuscript. Thanks are also due to Dr. Jin Sik Choi, Mr. Jong Man Kim, Mr. Sok Hyon Kim and $\mathrm{Mr}$. Bu Gun Jeung of Gyeongsang National University for their kind cooperation in the course of field investigations in Korea. The senior author also thanks Dr. Tae Gyu Yoon, the ex-President of the University, for his help promoting the present study and encouragement.

\section{REFERENCES}

Higashi, S. 1974 Worker polyethism related with body size in a polydomous red wood ant, Formica (Formica) yessensis Forel. J.Fac. Sci., Hokkaido Univ., Ser. VI, Zool., 19: 695-705

Higashi, S. 1976 Nest proliferation by budding and nest growth pattern in Formica (Formica) yessensis in Ishikari Shore. J.Fac. Sci., Hokkaido Univ., Ser. VI, Zool., 20: 359-389

Higashi, S. 1978a Task and area1 conservatism and internest drifting in a red wood ant Formica (Formica) yessensis Forel. Jap. J. Ecol., $28: 307-317$

Higashi, S. 1978b Analysis of internest drifting in a supercolonial ant Formica (Formica)

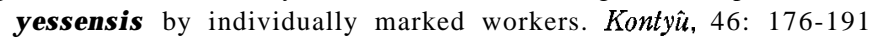

Imamura, S. 1974 Observations on the hibernation of a polydomous ant, Formica (Formica) yessensis Forel. J.Fac. Sci., Hokkaido Univ., Ser. VI, Zool., 19: 438-444

Imamura, S. 1976 Life of Formica yessensis Forel. Anima, 4 (3) : 13-20 (in Japanese)

Imamura, S. 1978 Adult transport in a supercolony of Formica (Formica) yessensis Forel. with special reference to its relation with digging. Jap.J. Ecol., 28: 73-84

Ito, M. 1971 Nest distribution of Formica yessensis Fore1 in Ishikari Shore, in reference to plant zonation. J. Fac. Sci., Hokkaido Univ., Ser. VI,Zool., 18: 144-154

Ito, M. 1973 Seasonal population trends and nest structure in a polydomous ant, Formica (Formica) yessensis Forel. J. Fac. Sci., Hokkaido Univ., Ser. VI, Zool., 19 : 270-293

Ito, M. and S. Imamura 1974 Observations on the nuptial flight and internidal relationship in a polydomous ant, Formica (Formica) yessensis Forel. J. Fac. Sci., Hokkaido Univ., Ser. VI, Zool., 19: 681-694

Kim, C. H., J. S. Choi and S. H. Kim 1978 Studies on the biological control of pine caterpillar (Dendrolimus spectabilis Butler) by red wood ants (Formica rufa truncicola var. yessensis Forel). J. Inst. Agr. Resource Util., Gyeongsang Univ., 12: 91-123 (In Korean with English Summary)

Kim, C. H. and Y. Murakami 1980 Ecological studies on Formica yessensis Forel. with special reference to its effectiveness as a biological control agent of the pine caterpillar 
moth in Korea I. Geographical and ecological distributions of Formica yessensis Fore 1 (Hymenoptera: Formicidae). J.Fac. Agr., Kyushu Univ., 24: 239-245

Lee, J. 1938 Division of labor among the workers of the Asiatic carpenter ants (Camponotus japonicus var. aterrimus). Peking Nat. Hist. Bull., 13: 137-145

Scherba, G. 1961 Nest structure and reproduction in the mound-building ant Formica opaciventris Emery in Wyoming. J. New York Ent. Soc., 69: 71-87

Talbot, M. 1959 Flight activities of two species of ants of the genus Formica. Amer. Midl. Natur., 61: 124-132

Talbot, M. 1964 Nest structure and flights of the ant Formica obscuriventris Mayr. Anim. Behav., 12: 154-158 